Arq. Bras. Med. Vet. Zootec., v.69, n.6, p.1645-1652, 2017

\title{
Selection of autochtone probiotic for Astyanax bimaculatus
}

[Seleção de probiótico autóctone para Astyanax bimaculatus]

\author{
A. Jatobá ${ }^{1}$, A.V. Moraes $^{1}$, L.D. Steckert ${ }^{1,2}$, G.F.A. Jesus ${ }^{2}$
}

${ }^{1}$ Laboratório de Aquicultura, Instituto Federal Catarinense - Araquari, SC

${ }^{2}$ Universidade Federal de Santa Catarina - Florianópolis, SC

\begin{abstract}
This study aimed to isolate native lactic acid bacteria of yellow tail lambari (Astyanax bimaculatus) and evaluate their effect on host microbiota and gut morphology, as well as survival after experimental challenge. The isolated bacterial strains were evaluated for their inhibition against pathogenic bacterial strains in vitro, and the strain with highest inhibitory ability was molecularly identified as Lactobacillus spp. For in vivo testing, eighty fish were distributed in ten tanks equipped with a recirculation system. The experimental units were divided into two treatments: fish fed with Lactobacillus spp. supplement and fish fed an unsupplemented diet (control). After 30 days, guts from three fish from each experimental unit were pooled for microbiological and histological analysis. The other five fish were inoculated with $2.1 \times 10^{4} \mathrm{CFU} . \mathrm{mL}^{-1}$ of Aeromonas hydrophila to evaluate survival after $24 \mathrm{~h}$. Lambaris fed with the probiotic diet had a lower count of Vibrios spp., Pseudomonas spp. and Staphylococcus spp., and a higher count of lactic acid bacteria compared to control treatment, as well as, increased length, width and perimeter of intestinal villi, as well as higher survival rate (16.2\%) after experimental challenge compared to the unsupplemented group. The results show that the Lactobacillus spp. used has effect probiotic for yellow tail lambari.
\end{abstract}

Keywords: Lactobacillus, yellow tail lambari, gut morphology, microbiota, experimental challenge

\section{RESUMO}

Este estudo objetivou isolar bactéria ácido-láctica nativa do lambari-do-rabo-amarelo (Astyanax bimaculatus) e seu efeito na microbiota e morfologia do trato digestório do hospedeiro, assim como a sobrevivência após um desafio experimental. As bactérias isoladas foram avaliadas quanto a suas inibições in vitro contra bactérias patogênicas; a cepa com maior capacidade de inibição foi identificada como Lactobacillus spp. Para o teste in vivo, 80 peixes foram distribuídos em 10 tanques equipados com sistema de recirculação. As unidades experimentais foram divididas em dois tratamentos: peixes alimentados com Lactobacillus spp. suplementado e peixes alimentados com dieta não suplementada (controle). Após 30 dias, foram coletados o trato intestinal de três peixes, por unidade experimental, para


Aeromonas hydrophila para se avaliar a sobrevivência após 24h. Lambaris alimentados com probiótico apresentaram menor contagem de Vibrios spp., Pseudomonas spp. e Staphylococcus spp., e maior de bactérias ácido-lácticas quando comparados com o tratamento controle, assim como aumento do comprimento, da largura e do perímetro das vilosidades intestinais e maior taxa de sobrevivência $(16,2 \%$,) após desafio experimental, em comparação com o grupo sem suplementação. Os resultados mostram que o Lactobacillus spp. possui efeito probiótico para o lambari-do-rabo-amarelo.

Palavras-chave: Lactobacillus, lambari-do-rabo-amarelo, morfologia do intestino, microbiota, desafio experimental

Recebido em 10 de maio de 2016

Aceito em 3 de fevereiro de 2017

E-mail: jatobaadolfo@gmail.com 


\section{INTRODUCTION}

In Brazil, fish farming improved its production by $20.9 \%$, from 392,000 tons in 2013 to 474,000 tons in 2014. Among the species with increased production, the genus Astyanax, popularly known as lambaris or characins, saw an increase of $6.0 \%$ in the same period (Produção..., 2015).

This genus is represented by about a hundred species with broad geographic distribution and rather confusing taxonomy. Astyanax fasciatus, A. scabripinnis, A. altiparanae and $A$. bimaculatus are all small lambaris with a rapid six-month life cycle. They easily accept natural food, as well as artificial feeding, and they can swim in shoals, which facilitates their culture in intensive systems (Jatobá and Silva, 2015).

In aquaculture, especially in fish and shrimp farming, the expansion of production areas and intensification of culture systems have led to the emergence of various bacterial, parasitic and viral diseases throughout the world (Kumar et al., 2014; Mo et al., 2015; Hai, 2015; Raja e Jithendran, 2015). To combat the spread of disease, antibiotics are typically applied.

Antibiotics are defined as any substance produced by microorganisms that kill or inhibit the growth of other microorganisms, this definition excludes synthetic antibacterial compounds. For diseases of bacterial origin, these compounds are widely used, but their indiscriminate use in various activities, including aquaculture, has resulted in the emergence of resistant bacterial strains (Bloch et al., 2013). As an alternative, the use of probiotics has emerged (Balcázar et al., 2008; Newaj-fyzul et al., 2014; Raja e Jithendran, 2015). Probiotics may be defined as live microorganisms that colonize the digestive tract of aquaculture animals in order to improve their health (Gatesoupe, 1999), and in the aquaculture industry, they are mainly used as a prophylactic measure (Ringø et al., 2014).

Among the microorganisms with probiotic potential, increasing interest has turned to the use of lactic acid bacteria (LAB) based on their ability to inhibit the growth of pathogenic bacteria by the production of antimicrobial compounds, such as bacteriocins, hydrogen peroxide acid, lactic acid and reuterin (Balcázar et al., 2008; Newaj-fyzul et al., 2014). Indeed, the use of LAB has shown beneficial effects in various aquatic organisms, such as Centropomus spp (Carnevali et al., 2006; Barbosa et al., 2011), Oreochromis niloticus juveniles (Jatobá et al., 2008, 2011) and fingerlings (Jatobá e Mourinõ, 2015), Pseudoplatystoma sp. (Mouriño et al., 2012) and Litopenaeus vannamei (Vieira et al., 2008; Jatobá et al., 2011). In all of these species, studies have reported positive changes in host microbiota and immune defense.

Microorganisms originating from almost anywhere in the aquatic environment can be utilized as probiotics, as long as the efficacy their effects have been confirmed (Ringø et al., 2014). However, several authors (Carnevali et al., 2006; Vieira et al., 2008; Jatobá et al., 2008, 2011; Merrifield et al., 2010; Mouriño et al., 2012) have suggested screening bacteria from the digestive tract of hosts to isolate potential probiotics. Such selection is based on the theory that native microorganisms increase the chances of colonizing the intestinal tract, a key selection criterion (Gatesoupe, 2008; Jatobá et al., 2008; Merrifield et al., 2010; Mouriño et al., 2012). As a result of colonization, an improvement in immunocompetence is expected with respect to acquired and innate immunity through the modulation of intestinal mucosa (Lazado and Caipang, 2014).

For fish from the Astyanax family, there is no record of the use of probiotics, demonstrating the lack about this subject. Thus, this study aimed to isolate native lactic acid bacteria (LAB) of yellow tail lambari (A. bimaculatus) and evaluate their effect on host microbiota and gut morphology, as well as survival rate after experimental challenge.

\section{MATERIALS AND METHODS}

The study was carried out in the Laboratório de Aquicultura (LAQ), Instituto Federal Catarinense (IFC), campus Araquari, (Protocol number $0005 / 2013$ approved by by animal ethics committee).

Strains were isolated, as described by Jatobá et al. (2008), from the digestive tract of 16 yellow tail lambari $(12.3 \pm 4.3 \mathrm{~g})$ obtained from the LAQ. Fish were anesthetized by eugenol $\left(75 \mathrm{mg} \mathrm{L}^{-1}\right)$ and euthanized by cranial concussion. The digestive tracts of collected fish were removed under sterile conditions, macerated in $0.65 \%$ 
$\mathrm{NaCl}$ sterile saline, sprayed on plates with de Man, Rogosa, and Sharpe (MRS) modified (Ramires et al., 2006) growth media, and incubated for 48 hours at $30^{\circ} \mathrm{C}$. After incubation, the colonies grown in culture media were identified morphologically using Gram's Method. Colonies of interest were spread on Petri dishes containing MRS growth media using the streaking method for isolation.

The bacterial strains isolated from fish were evaluated for their ability to inhibit Gramnegative (Escherichia coli ATCC 363 and Aeromonas hydrophila ATCC 7966) and Grampositive (Enterococcus durans ATCC 19432 and Micrococcus luteus ATCC 270) pathogenic bacterial strains in vitro. To that end, Petri dishes containing MRS Agar growth medium were sprayed with the bacterial strains isolated from lambaris and incubated at $30^{\circ} \mathrm{C}$ for 48 hours. After that period, new Petri dishes were sprayed with one of the pathogenic strains in Plate Count Agar (PCA). Agar disks were removed $(0.8 \mathrm{~cm}$ in diameter) from the Petri dishes containing the initially isolated and grown bacteria. These agar disks were placed on the growth medium of the discs just sown with pathogens and incubated at $30^{\circ} \mathrm{C}$ for 24 hours. Pathogen growth inhibition was determined by the diameter of the halo produced around the agar disk.

Strains showing the highest inhibition zones were sent to the Centro Pluridisciplinar de Pesquisas Químicas, Biológicas e Agrícolas (CPQBA), Universidade Estadual de Campinas (UNICAMP), for molecular identification.

The commercial feed, consisting of $2 \mathrm{~mm}$ extruded diet, crude protein $32 \%$, moisture $8 \%$, crude fat $6.5 \%$, crude fiber $7 \%$, calcium $1.2 \%$, phosphorus $0.6 \%$, ash $10 \%$ (Guabi Group, Brazil), was sprayed with the selected lactic acid bacterium previously grown in MRS at a concentration of $1 \times 10^{11} \mathrm{CFUmL}^{-1}$ and rate of $100 \mathrm{~mL} \mathrm{~kg}^{-1}$ feed. The sprayed feed was incubated for $24 \mathrm{~h}$ at $35^{\circ} \mathrm{C}$ in a hermetically sealed container. Next, the feed was dried in an oven for $24 \mathrm{~h}$ at $35^{\circ} \mathrm{C}$. The control feed was sprayed with a sterile MRS culture medium. To quantify LAB content in the feed, five serial dilutions (1:10) were carried out. The $10^{3}, 10^{4}$, and $10^{5}$ dilutions were grown in a modified MRS (Ramires et al., 2006). The final LAB count in the supplemented feed was $1 \times 10^{7}$ colony forming units (CFU) $\mathrm{g}^{-1}$ feed (Jatobá et al., 2008).

For in vivo assay, eighty lambaris (mean weight $8.7 \pm 1.3 \mathrm{~g}$ ) were distributed in ten $22 \mathrm{~L}$ polyethylene tanks $(\mathrm{n}=8 / \operatorname{tank})$ connected to a recirculation system with a canister filter and constant temperature $\left(26-28^{\circ}\right)$. The experimental units were divided into two treatments: fish fed the selected LAB diet and fish fed with control diet (without supplementation). Fish were fed four times a day, with $3 \%$ of the biomass, for 30 days. During the experiment, dissolved oxygen and temperature were measured twice a day. The $\mathrm{pH}$, total dissolved ammonia and nitrite were measured twice a week. Water parameters during the assay were kept as follows: dissolved oxygen $5.11 \pm 0.42 \mathrm{mg} \mathrm{L}^{-1}$, total ammonia $0.12 \pm 0.03 \mathrm{mg}$ $\mathrm{L}^{-1}$, nitrite $0.02 \pm 0.01 \mathrm{mg} \mathrm{L}^{-1}$ and $\mathrm{pH} 7.02 \pm 0.08$. All water quality parameters remained ideal for the production of the A. bimaculatus.

Following 24h of starvation at the end of the experimental period, guts of three fish from each tank were removed and pooled to microbiological and histological analysis. The pooled fish guts were homogenized and serially diluted $1: 10$ in $0.65 \%$ of $\mathrm{NaCl}$ sterile saline. Samples from each dilution were cultured in PCA, TCBS (thiosulfate citrate bile salts sucrose) agar, cetrimide agar, and MRS agar media and incubated for $48 \mathrm{~h}$ at $30^{\circ} \mathrm{C}$ for viable culturable heterotrophic bacterial counts, including Vibrio spp., Pseudomonas spp., and $\mathrm{LAB}$, respectively.

Samples from the anterior region of fish (same fish used in microbiological test) intestine were collected from three fish per tank (Silva et al., 2010 ) and fixed in FBS $10 \%$ during 48h. After fixation, the samples were washed and dehydrated in crescent series of ethanol. After dehydration, the samples were embedded in paraffin. Sections $5 \mu \mathrm{m}$ thick were stained with hematoxylin and eosin, and photomicrographs were made using an Epifluorescent microscope (Olympus BX 41) equipped with Image Q Capture Pro 5.1 software (QImaging Corporation, Austin, TX, USA). From the images, it was possible to measure the length, width and perimeter of the villi $(\mu \mathrm{m})$.

Previously the in vivo assay was performed the DL50 or lethal dose 50 (concentration of 
Aeromonas hydrophila necessary substance to kill $50 \%$ of specimens in experience at given time). For this, 150 yellow tail lambari (A. bimaculatus), mean weight $10.2 \pm 0.3 \mathrm{~g}$, were distributed in 15 aquaria, 10 fish per aquarium, all equipped with biological filter and constant temperature $\left(24-25^{\circ} \mathrm{C}\right)$. The pathogenic bacterium A. hydrophila (ATCC 7966) was cultured in brain heart infusion medium (BHI) at $30^{\circ} \mathrm{C}$ for 24 hours, followed by centrifugation at $1.000 \mathrm{~g}$ for $15 \mathrm{~min}$. The supernatant was discarded, and the bacterial pellet was resuspended in $0.65 \% \mathrm{NaCl}$ sterile saline. After incubation, the culture was serially diluted $(1: 10)$ to $10^{8}$ and plated on PCA to determine the bacterial concentration of the starting inoculum. To construct a growth curve, bacterial inocula were serially diluted $(1: 2)$ in triplicate in 96-well microtiter plates 12 times, and the absorbance of each well was measured at $630 \mathrm{~nm}$ using a microplate reader. Inoculum concentration was adjusted to $2.1 \times 10^{3}, 2.1 \times 10^{4}, 2.1 \times 10^{5}, 2.1 \times 10^{6}$ and $2.1 \times 10^{7} \mathrm{CFU} \mathrm{mL} \mathrm{m}^{-1}$ with $0.65 \%$ sterile saline. All fish were inoculated with $100 \mu \mathrm{L}$ of $A$. hydrophila, and cumulative mortality of fish was evaluated after 24 hours.

For the experimental infection, at the end of the experimental period, a pure bacterial culture grown in BHI broth for $30^{\circ} \mathrm{C}$ for $24 \mathrm{~h}$ in static incubation was centrifuged for $30 \mathrm{~min}$ at $1800 \mathrm{~g}$. The supernatant was discarded, and the pellet was resuspended in $0.65 \%$ sterile saline to adjust the concentration of the bacteria defined by DL 50. In this step, five fish (different from those previously used) from each experimental unit (25 per treatment) were inoculated with $100 \mu \mathrm{L}$ of $A$. hydrophila (ATCC 7966) at concentration of $2.1 \times 10^{4} \mathrm{CFUmL}^{-1}$. After 24 hours, fish survival was evaluated.
All data were first subjected to Bartlett's analysis to verify the homogeneity of variance. Then data from in vitro selection of $\mathrm{LAB}$ were subjected to one-way ANOVA, and significant differences among treatments were analyzed using the Student-Newman-Keuls (SNK) test. For the in vivo test, microbiological data were $\log (\mathrm{x}+1)$ transformed, and all data were assessed by Student's - $t$ test. All tests were conducted at a $5 \%$ level of significance.

\section{RESULTS AND DISCUSSION}

Twenty-four LAB strains were isolated from the intestinal tract of lambaris. Of these, 18 were discarded for presenting unsatisfactory growth and failure to adapt to laboratory conditions. Successful use of LAB in aquaculture has been reported by several authors. Different stages of bacterial life cycle and different farming systems were studied (Carnevali et al., 2006; Vieira et al., 2008; Jatobá et al., 2008, 2011; Merrifield et al., 2010; Mouriño et al., 2012). All studies suggested the use of LAB as a potential probiotic substitute for antibiotics.

Antagonism to pathogenic bacteria is a main determinant for the in vivo selection of desirable microorganisms. Of the six strains used for the in vitro selection test in the present study, Lactobacillus spp. showed the highest inhibition zone $(17.4 \mathrm{~mm})$ and had the greatest inhibitory effect on Micrococcus luteus, Aeromonas hydrophyla and Pseudomonas aeruginosa (Table 1). Inhibition halos formed against Gramnegative bacteria can be associated with such bactericidal substances as high molecular weight (MW) bacteriocins, low MW reuterin, lactic acid and acetic acid and hydrogen peroxide (Balcázar et al., 2008; Newaj-fyzul et al., 2014).

Table 1. Inhibition halos (mean \pm standard deviation, $\mathrm{mm}$ ) of indigenous lactic acid bacteria isolated from intestinal tract of yellow tail lambari (Astyanax bimaculatus) against strains of pathogenic bacteria

\begin{tabular}{cccccc}
\hline $\begin{array}{c}\text { Lactic Acid } \\
\text { Bacteria }\end{array}$ & $\begin{array}{c}\text { Micrococcus } \\
\text { luteos }\end{array}$ & $\begin{array}{c}\text { Enterococcus } \\
\text { durans }\end{array}$ & $\begin{array}{c}\text { Aeromonas } \\
\text { hydrophyla }\end{array}$ & $\begin{array}{c}\text { Pseudomonas } \\
\text { aeroginosa }\end{array}$ & Average \\
\hline Lactobacillus spp. & $26.6 \pm 1.3 \mathrm{a}$ & $10.5 \pm 1.5 \mathrm{~b}$ & $13.0 \pm 1.5 \mathrm{ab}$ & $20.0 \pm 1.0 \mathrm{a}$ & $17.4 \pm 7.4$ \\
LA1 & $15.0 \pm 1.0 \mathrm{c}$ & $0.0 \pm 0.0 \mathrm{c}$ & $10.0 \pm 0.0 \mathrm{c}$ & $10.0 \pm 0.5 \mathrm{c}$ & $8.8 \pm 6.3$ \\
LA4 & $13.3 \pm 1.6 \mathrm{c}$ & $10.0 \pm 1.0 \mathrm{~b}$ & $10.0 \pm 1.0 \mathrm{c}$ & $10.0 \pm 1.0 \mathrm{c}$ & $10.8 \pm 1.7$ \\
LA8 & $25.0 \pm 1.0 \mathrm{a}$ & $15.0 \pm 0.0 \mathrm{a}$ & $12.5 \pm 0.0 \mathrm{~b}$ & $15.0 \pm 0.0 \mathrm{~b}$ & $16.9 \pm 5.5$ \\
LA12 & $10.0 \pm 0.0 \mathrm{~d}$ & $0.0 \pm 0.0 \mathrm{c}$ & $15.0 \pm 1.0 \mathrm{a}$ & $0.0 \pm 0.0 \mathrm{~d}$ & $6.3 \pm 7.5$ \\
LA21 & $18.3 \pm 1.3 \mathrm{~b}$ & $10.0 \pm 0.0 \mathrm{~b}$ & $11.0 \pm 2.0 \mathrm{bc}$ & $10.0 \pm 1.0 \mathrm{c}$ & $12.1 \pm 4.2$ \\
Significance & 0.03976 & 0.01974 & 0.04350 & 0.00935 & \\
\hline
\end{tabular}

*Different letters indicate significant differences $(\mathrm{P}<0.05)$ between treatments using one-way ANOVA and SNK for mean separation. 
Previously, Lactobacillus plantarum isolated from Oreochromis niloticus and Litopenaeus vannamei showed inhibition zones greater than oxytetracycline and enrofloxacin, as well as the ability to inhibit pathogenic bacteria (Jatobá et al., 2008; Vieira et al., 2008). The results presented by Lactobacillus spp. isolated from lambari suggest greater efficacy than antibiotics, even without performing an antibiogram. Finally, the lactic acid bacterium isolated with the best in vitro results was molecularly identified as belonging to Lactobacillus spp. (CPQBA 116815 DRM-01).
Unlike terrestrial organisms, the intestinal host microbiota of aquatic organisms predominantly consists of gram-negative bacteria (Gomez-gil et al., 2000) and may vary according to the environment, a shortage of any nutrient, or the use of probiotic bacteria (Gatesoupe, 2008). Lambaris fed a probiotic diet had a lower count of Vibrios, Pseudomonas and Staphylococcus and a higher count of LAB when compared to control treatment. The concentration of viable culturable heterotrophic bacteria did not differ between treatments (Figure 1).

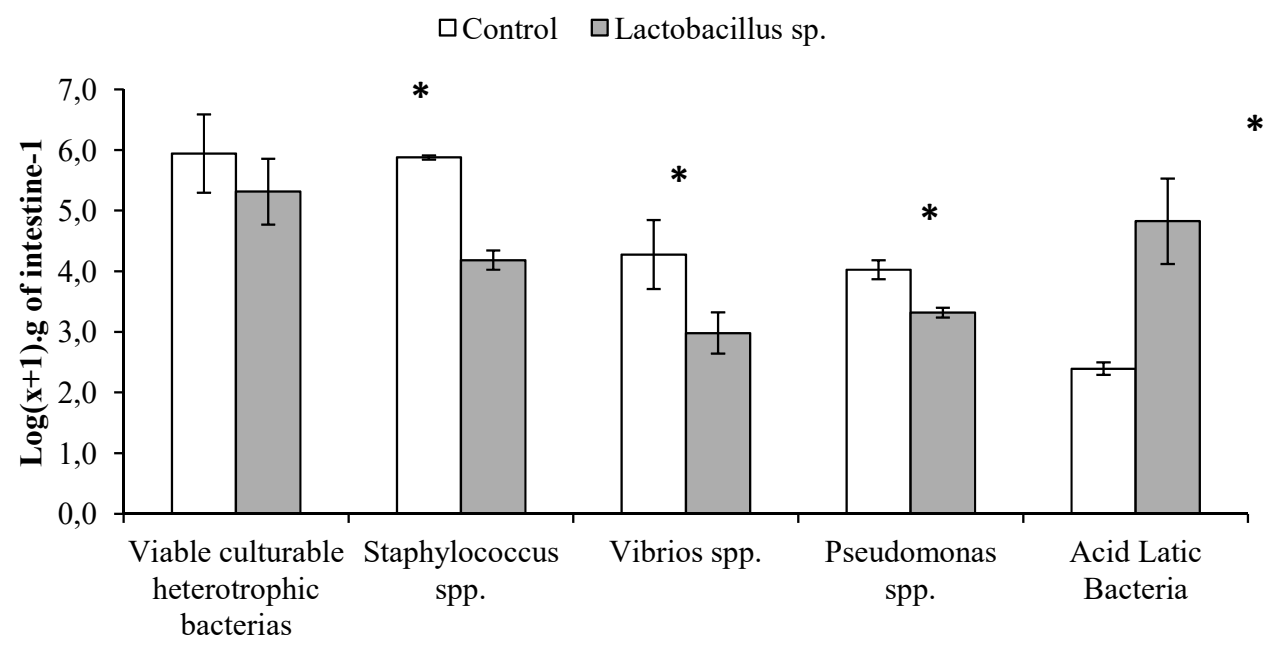

Figure 1. Bacterial counts in the gut of yellow tail lambari (Astyanax bimaculatus) fed Lactobacillus spp. supplement (probiotic) and control (unsupplemented diet). ${ }^{*}$ Indicates significant difference $(\mathrm{P}<0.05)$ by $-t$ test between treatments.

The reduction in Vibrio sp. count can be attributed to the ability of LAB-supplemented diet to produce inhibitory substances (Vieira et al., 2008; Jatobá et al., 2008). More specifically, lactic acid bacteria are known as producers of antimicrobial compounds (Balcázar et al., 2008). For example, Lactobacillus plantarum produces a bacteriocin known as plantaricin (Hernández et al., 2005), which may be related to the formation of growth inhibition halos against the Grampositive bacteria analyzed in this research.

LAB supplied as a probiotic has been found to cause changes in the microbiota of host organisms (Gatesoupe, 1999; Newaj-fyzul et al., 2014). Among the main changes is the increase in LAB and decrease of vibrios. These results were observed in Centropomus spp. (Barbosa et al., 2011), O. niloticus juveniles (Jatobá et al., 2008, 2011) and fingerlings (Jatobá and Mouriño, 2015), Pseudoplatystoma sp. (Mouriño et al., 2012) and L. vannamei (Vieira et al., 2008; Jatobá et al., 2011). For Staphylococcus and Pseudomonas, the results vary widely according to the probiotic microorganism and host, as well as interaction between them, but in general, LAB can inhibit a wide range of bacteria commonly found in fish microbiota.

In light microscopy, the probiotic group showed morphological differences in length, width and perimeter of the villi compared to the 
unsupplemented group (Table 2). All examined intestinal sections appeared normal and healthy with no signs of detached and necrotic enterocytes. Well-developed villi without necrosis were observed (Figure 2). The same effect was verified by Gisbert et al. (2013) who supplemented rainbow trout fingerlings (Oncorhynchus mykiss) with Bacillus cereus var. toyoi for 93 days. These fish showed larger villi than those fed with the control diet. The results of the present study showed that probiotic supplementation can improve villous length and/or perimeter ratio. Higher perimeter ratios suggest higher intestinal surface area for nutrient absorption. Corroborating results can be found in another study where Nile tilapia (O. niloticus) was supplemented with Lactobacillus rhamnosus GG for 30 days (Pirarat et al., 2011).

Table 2. Length, width and villi perimeter of yellow tail lambari (Astyanax bimaculatus) fed Lactobacillus spp. supplement (probiotic) and control (unsupplemented diet)

\begin{tabular}{cccc}
\hline Treatment & Length $(\mathrm{mm})$ & Width $(\mathrm{mm})$ & Perimeter $(\mathrm{mm})$ \\
\hline Control & $189.0 \pm 6.6$ & $67.6 \pm 4.8$ & $418.9 \pm 12.4$ \\
Probiotic & $201.3 \pm 3.6^{*}$ & $74.9 \pm 2.2^{*}$ & $459.0 \pm 26.0^{*}$ \\
Significance $(p)$ & 0.023701 & 0.038026 & 0.036685 \\
\hline
\end{tabular}

*Indicates significant difference by- $t$ test between.

Increased intestinal morphometry may be related to the ability of probiotic bacteria to inhibit the adhesion of pathogenic bacteria to the intestinal epithelium, thus protecting the villi and the absorbent surfaces against irritating toxins produced by pathogenic microorganisms (Ukena et al., 2007). In this sense, the increase of intestinal morphometry can be directly related to the reduction in Vibrio sp., Pseudomonas and Staphylococcus count, and higher LAB count when compared to the unsupplemented treatment.
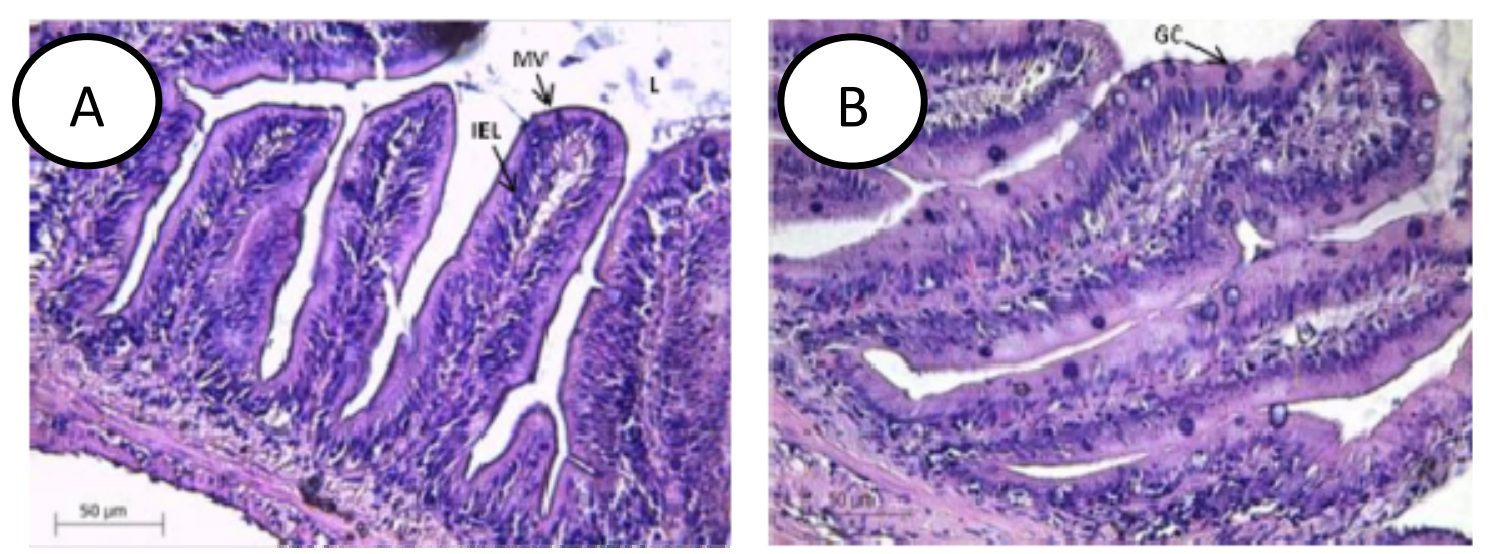

Figure 2. Photomicrographs of intestinal epithelium of yellow tail lambari (A. bimaculatus) fed or not fed diet supplemented with Lactobacillus spp. for 30 days. A) histological section of unsupplemented fish; B) histological section of supplemented fish. GC-goblet cell, IEL-intraepithelial lymphocyte-like cell, Llumen, MV-microvilli.

After experimental challenge, lambaris fed the probiotic-supplemented diet showed a survival rate of $65.5 \pm 9.6 \%$. This result was $16.2 \%$ higher $(\mathrm{P}=0.04112)$ than that of fish fed with control diet $(49.3 \pm 12.2 \%)$, and it can be directly related to the ability of probiotics to stimulate greater migration of defense cells to infection sites, as observed by Dotta et al. (2011) who fed Nile tilapia (O. niloticus) a diet supplemented with $L$. plantarum, the same strain used by Jatobá et al. (2008, 2011), and carried out an experimental challenge with carrageenan.

It is difficult to confirm the exact mechanism by which probiotics improve the health of aquatic animals. In higher vertebrates, lactic acid producing bacteria can directly interact with immune cells through specialized cells in the 
intestinal epithelium, i.e., microfold, or $\mathrm{M}$ cells, inducing their activation and proliferation, even in the absence of contact with the circulatory system (Gill, 2003). This result demonstrates the potential of Lactobacillus spp. to improve survival after experimental challenge, in turn confirming the efficacy of the in vitro selection procedure used.

Although the route of infection used in the experimental challenge was different from that employed in culture medium, the greater survival rate of animals fed with a probiotic diet suggests the potential of this bacterium to reduce the production losses that result from disease, adding the cautionary note that the method still needs to be evaluated under farming conditions. Based on the preventive effect of Lactobaccilus plantarum against bacterial diseases in Nile tilapia $(O$. niloticus), as observed by Jatobá et al. (2008), the same results can be expected for lambaris fed a diet supplemented with Lactobacillus spp.

In conclusion, Lactobacillus spp. isolated in this study has probiotic properties based on positive changes in gut morphology and host microbiota. Furthermore, lactic acid bacteria were demonstrated to increase survival rate against Aeromonas hydrophila.

\section{ACKNOWLEDGMENTS}

The authors of this study acknowledge Conselho Nacional de Desenvolvimento Científico e Tecnológico (CNPq, 460362/2014-3 and 23/2016 IFC/CNPq) and Fundação de Amparo à Pesquisa e Inovação do Estado de Santa Catarina (FAPESC) for supporting and offering scholarship for the development of the project; GUABI for financing the diets used; and Klayton Moraes, Luiz Sérgio Moreira, Marina de Oliveira Pereira for technical support.

\section{REFERENCES}

BALCÁZAR, J.L.; VENDRELL, D.; BLAS, I.; et al. Characterization of probiotic properties of lactic acid bacteria isolated from intestinal microbiota of fish. Aquaculture, v.278, p.188191, 2008

BARBOSA, M.C.; JATOBÁ, A.; VIEIRA, F.D.N.; et al. Cultivation of juvenile fat snook (Centropomus parallelus Poey, 1860) fed probiotic in laboratory conditions. Braz. Arch. Biol. Technol., v.54, p.795-801, 2011.

BLOCH, E.F.; SCHULTZ, R.D.; TURNER, W. "Mini-review: probiotics and disease prevention in different host systems. Br. Microbiol. Res. J., v.42, p.42-57, 2013.

CARNEVALI, O.; VIVO, L.; SULPIZIO, R. et al. Growth improvement by probiotic in European sea bass juveniles (Dicentrarchus labrax, L.), with particular attention to IGF-1, myostatin and cortisol gene expression. Aquaculture, v.258, p.430-438, 2006.

DE MAN, J.C.; ROGOSA, M.; SHARPE, M.E. A medium for the cultivation of lactobacilli. $J$. Appl. Bacteriol., v.23, p.130-135, 1960.

DOTTA, G.; MOURIÑO, J.LP.; JATOBÁ, A. et al. Acute inflammatory response in Nile tilapia fed probiotic Lactobacillus plantarum in the diet. Acta Sci. Biol. Sci., v.33, p.239-246, 2011.

GATESOUPE, F.J. The use of probiotics in aquaculture. Aquaculture, v.180, p.147-165, 1999.

GATESOUPE, F.J. Updating the importance of lactic acid bacteria in fish farming: natural occurrence and probiotic treatments. J. Mol. Microbiol. Biotechnol., v.14, p.107-114, 2008.

GILL, H.S. Probiotics to enhance anti-infective defences in the gastrointestinal tract. Best Pract. Res. Clin. Gastroenterol., v.17, p.755-773, 2003.

GISBERT, E.; CASTILLO, M.; SKALLI, A.; et al. Bacillus cereus var. toyoi var. promotes growth, affects the histological organization and microbiota of the intestinal mucosa in rainbow trout fingerlings. J. Anim. Sci., v.91, p.27662774, 2013.

GOMEZ-GIL, B.; ROQUE, A.; TURNBULL, J.F. The use and selection of probiotic bacteria for use in the culture of larval aquatic organisms. Aquaculture, v.191, p.259-270, 2000.

HAI, N.V. The use of probiotics in aquaculture. J. Appl. Microbiol., v.119, p.917-935, 2015.

HERNANDEZ, D.; CARDELL, E.; ZARATE, V. Antimicrobial activity of lactic acid bacteria isolated from Tenerife cheese: initial characterization of plantaricin TF711, a bacteriocin-like substance produced by Lactobacillus plantarum TF711. J. Appl. Microbiol., v.99, p.77-84, 2005. 
JATOBÁ, A.; MOURIÑO, J.L.P. Lactobacillus plantarum effect on intestinal tract of Oreochromis niloticus fingerlings. Cienc. Anim. Bras., v.16, p.45-53, 2015.

JATOBÁ, A.; SILVA, B.C. Stocking density in the juvenile production of two characins species in a recirculating system. Arq. Bras. Med. Vet. Zootec., v.67, p.1469-1474, 2015.

JATOBÁ, A.; VIEIRA, F.N.; BUGLIONE, N.C. et al. Lactic-acid bacteria isolated from the intestinal tract of Nile tilapia utilized as probiotic. Pesqui. Agropecu. Bras., v.43, p.12011207, 2008

JATOBÁ, A.; VIEIRA, F.N.; BUGLIONE, N.C.C. et al. Diet supplemented with probiotic for Nile tilapia in polyculture system with marine shrimp. Fish Physiol. Biochem., v.37, p.725-732, 2011.

KUMAR, B.K.; DEEKSHIT, V.K.; RAJ, J.R.M. et al. Diversity of vibrio parahaemolyticus associated with disease outbreak among cultured Litopenaeus vannamei (Pacific white shrimp) in India. Aquaculture, v.433, p.247-251, 2014.

LAZADO, C.C.; CAIPANG, C.MA. Mucosal immunity and probiotics in fish. Fish Shellfish Immunol., v.39, p.78-89, 2014.

MERRIFIELD, D.L.; DIMITROGLOU, A.; FOEY, A. et al. The current status and future focus of probiotic and prebiotic applications for salmonids. Aquaculture, v.302, p.1-18, 2010.

MO, Z.Q.; ZHOU, L.; ZHANG, X. et al. Outbreak of Edwardsiella tarda infection in farm-cultured giant mottled eel Anguilla marmorata in China. Fish. Sci., v.81, p.899-905, 2015.

MOURIÑO, J.L.P.; VIEIRA, F.N.; JATOBÁ, A.B. et al. Effect of dietary supplementation of inulin and W. cibaria on haemato-immunological parameters of hybrid surubim (Pseudoplatystoma sp). Aquac. Nutr., v.18, p.73-80, 2012.
NEWAJ-FYZUL, A.; AL-HARBI, A.H.; AUSTIN, B. Review: developments in the use of probiotics for disease control in aquaculture. Aquaculture, v.431, p.1-11, 2014.

PIRARAT, N.; PINPIMAI, K.; ENDO, M. et al. Modulation of intestinal morphology and immunity in Nile tilapia (Oreochromis niloticus) by Lactobacillus rhamnosus GG. Res. Vet. Sci., v.91, p.e92-e97, 2011.

PRODUÇÃO da Pesqueira Municipal. [Rio de Janeiro]: IBGE, 2015.

RAJA, R.A.; JITHENDRAN, K.P. Aquaculture disease diagnosis and health management. In: PERUMAL, S. et al. (Eds.). Advances in marine and Brackishwater aquaculture. [Berlin]: Springer, 2015. p.247-255.

RAMÍREZ, C.; BOLÍVAR, A.; CIFFONI, G.A.; PANCHENIAK, E.M.G.; SOCCOL, E.F.R.C. Microorganismos lácticos probióticos para ser aplicados en la alimentación de larvas de camarón y peces como substituto de antibiótico. Aliment. Lat. Am., v.264, p.70-78, 2006.

RINGØ, E.; OLSEN, R.E.; JENSEN, I.N. et al. Application of vaccines and dietary supplements in aquaculture: possibilities and challenges. Rev. Fish Biol. Fisher, v.24, p.1005-1032, 2014.

SILVA, L.C.R.; FURUYA, W.M.; NATALI, M.R.M. et al. Productive performance and intestinal morphology of Nile tilapia juvenile fed diets with L-glutamine and L-glutamate. Rev. Bras. Zootec., v.39, p.1175-1179, 2010.

UKENA, S.N.; SINGH, A.; DRINGENBERG, U. et al. Probiotic Escherichia coli Nissle 1917 inhibits leaky gut by enhancing mucosal integrity. PloS One, v.2, p.1308, 2007.

VIEIRA, F.D.N.; BUGLIONE, N.C.C.; MOURIÑO, J.L.P. et al. Time-related action of Lactobacillus plantarum in the bacterial microbiota of shrimp digestive tract and its action as immunostimulant. Pesqui. Vet. Bras., v.43, p.763-769, 2008. 